\title{
Endemic trees in a tropical biodiversity hotspot imperilled by an invasive
} tree

Bellingham, Peter J; Tanner, Edmund V J; Martin, Patrick H; Healey, John; Burge, Olivia R

\section{Biological Conservation}

\author{
Published: 01/01/2018
}

Peer reviewed version

Cyswllt i'r cyhoeddiad / Link to publication

Dyfyniad o'r fersiwn a gyhoeddwyd / Citation for published version (APA):

Bellingham, P. J., Tanner, E. V. J., Martin, P. H., Healey, J., \& Burge, O. R. (2018). Endemic trees in a tropical biodiversity hotspot imperilled by an invasive tree. Biological Conservation, 217(1), 47-53. https://www.sciencedirect.com/science/article/pii/S0006320717313964

\footnotetext{
Hawliau Cyffredinol / General rights

Copyright and moral rights for the publications made accessible in the public portal are retained by the authors and/or other copyright owners and it is a condition of accessing publications that users recognise and abide by the legal requirements associated with these rights.

- Users may download and print one copy of any publication from the public portal for the purpose of private study or research.

- You may not further distribute the material or use it for any profit-making activity or commercial gain

- You may freely distribute the URL identifying the publication in the public portal ?
}

Take down policy

If you believe that this document breaches copyright please contact us providing details, and we will remove access to the work immediately and investigate your claim. 


\section{Endemic trees in a tropical biodiversity hotspot imperilled by an invasive tree}

2 Peter J. Bellingham ${ }^{1 *}$, Edmund V.J. Tanner², Patrick H. Martin ${ }^{3}$, John R. Healey ${ }^{4}$, and Olivia R. Burge ${ }^{1}$

$4 \quad{ }^{1}$ Landcare Research, P.O. Box 69040, Lincoln 7640, New Zealand

5 orcid.org/0000-0001-9646-4819

$6 \quad{ }^{2}$ Department of Plant Sciences, University of Cambridge, Cambridge CB2 3EA, U.K.

$7 \quad{ }^{3}$ Department of Biological Sciences, University of Denver, Denver, CO 80208, U.S.A.

$8{ }^{4}$ School of Environment, Natural Resources and Geography, Bangor University, Deiniol Road, Bangor

$9 \quad$ LL57 2UW, U.K.

*Correspondence author: email: bellinghamp@landcareresearch.co.nz; phone +64 33219611

Running head: Tree invasion reduces native tree diversity and richness.

Highlights:

- A non-native tree, Pittosporum undulatum, is invading Jamaican montane rain forests

- Its invasion accelerated after an intense hurricane in 1988 and has not slowed since

- Local-scale tree species richness and diversity declines the more it invades

- The percentage of stems of trees endemic to Jamaica declines the more it invades 
Non-native plants invade some tropical forests but there are few long-term studies of these invasions, and the consequences for plant richness and diversity are unclear. Repeated measurements of permanent plots in tropical montane rain forests in the Blue and John Crow Mountains National Park in Jamaica over 24 to 40 years coincided with invasion by a non-native tree, Pittosporum undulatum. By 2014, P. undulatum comprised, on average, $11.9 \%$ of stems $\geq 3 \mathrm{~cm}$ diameter and $10.4 \%$ of the basal area across 16 widespread plots within c. 250 ha of the forests. Across these plots, the more $P$. undulatum increased in basal area over 24 years, the greater the decline in local, plot-scale tree species richness, and the greater the reduction in the percentage of stems of endemic tree species. Plot-scale tree diversity (Shannon and Fisher's alpha) also declined the more $P$. undulatum basal area increased, but beta diversity across the plots was not reduced. Declines in local-scale tree species diversity and richness as the invasion progresses is especially concerning because Jamaica is a global biodiversity hotspot. Native birds disperse $P$. undulatum seeds widely, and future hurricanes will probably further increase its invasion by reducing canopy cover and therefore promoting growth rates of its established shade-tolerant seedlings. Remedial action is needed now to identify forest communities with greatest endemism, and to protect them through a continuing programme of control and removal of $P$. undulatum.

Keywords: biodiversity hotspot; Jamaica, Pittosporum undulatum; resilience; tree species richness; tropical montane rain forest

\section{Introduction} Invasions of ecosystems by non-native plants often cause homogenization of communities and altered ecosystem functions and services (Ehrenfeld, 2010; Pyšek et al., 2012; van Wilgen et al., 2008). The consequences of these invasions for the diversity and richness of resident native plant 
communities, and the extent to which richer and more diverse communities are invadable, are contentious (Fridley et al., 2007). Tropical rain forests are very species-rich and most are not currently invaded by non-native plants (e.g. Fine, 2002), but there are increasing incidences of nonnative tree invasions in tropical montane forests (Barbosa et al., 2017; Binggeli and Hamilton, 1993; Florens et al., 2016; Martin et al., 2004; Meyer, 1996). Plant invasions pose an emerging threat to these forests, compounding effects of deforestation and climate change (Martin and Bellingham, 2016), and forests on islands seem particularly susceptible (Denslow, 2003; Denslow and DeWalt, 2008; Kueffer et al., 2010; Pyšek et al., 2012).

Tropical montane forests are limited by low light levels (because of fog and cloud cover) and low soil nutrient concentrations (nitrogen, N, in particular) (Bruijnzeel et al., 2010; Dalling et al., 2016; Fahey et al., 2016). Non-native plants that invade these ecosystems can be more efficient than native species at using limiting resources (Funk and Vitousek, 2007). Many non-native tree species that invade tropical montane forests have shade-tolerant seedlings that can grow rapidly if forest canopies are disturbed (Funk, 2013; Martin et al., 2009). The rate of invasion of tropical montane rain forests in Jamaica by a shade-tolerant tree, Pittosporum undulatum Vent. (Pittosporaceae), increased sharply in the sixteen years after the forests were strongly affected by an intense hurricane (Bellingham et al., 2005), supporting a view that disturbance can play a catalytic role in the invasion of tropical forests (e.g. Dawson et al., 2015; Dillis et al., 2017; Murphy and Metcalfe, 2016). It remains unclear how many invasions promoted by disturbances in tropical forests are transient (Ackerman et al., 2017) or are widespread and persistent, especially if the plants are shade-tolerant (Murphy and Metcalfe, 2016).

The Greater Antilles of the Caribbean, including Jamaica, are invaded by c. 500 non-native plant species (Rojas-Sandoval et al., 2017). They are also a global hotspot for endemism (Myers et al., 2000). In Jamaica's tropical montane rain forests, $41 \%$ of the tree flora is endemic (Tanner, 1986). We have conducted repeated measurements of tree species composition, growth and mortality in 
these forests over periods up to 40 years, which coincided with invasion by a non-native tree, $P$. undulatum. Longitudinal assessments like these, along with experimental studies, are needed to determine the relationships between plant invasions and native plant richness and diversity because correlational studies, based on point-in-time assessments, do not provide compelling evidence (Catford et al., 2012; Fridley et al., 2007).

Pittosporum undulatum is a tree native to eastern Australia that grows to $14 \mathrm{~m}$ height (Grubb et al., 2013). It is invasive in South Africa and on several islands including Lord Howe Island, St Helena, and Hawaii (Pasiecznik and Rojas-Sandoval, 2015) and it occupies about 30\% of the forested area on the Azores (Silva et al., 2017). In Jamaica, it was intentionally introduced to the Cinchona Botanic Gardens on the southern slopes of the Blue Mountains in the late 19th century (Bellingham et al., 2005). By the 1970s, it had invaded nearby montane rain forests along the edges of trails (Grubb and Tanner, 1976). By the 1990s, P. undulatum was dominant in areas of secondary forest (McDonald and Healey, 2000; McDonald et al., 2003). By 2004, it had increasingly invaded longer-established natural forests (with canopies that range in height from 6 to $12 \mathrm{~m}$ and taller in gullies; Asprey and Robbins, 1953), and occurred in 69\% of forest plots, locally as canopy trees (Bellingham et al., 2005). Seedlings of $P$. undulatum in these forests grow to become mature canopy trees within 24 to 35 years after the creation of experimental canopy gaps (Chai et al., 2012). In this study, we evaluate whether the rapid increase in invasion observed in the 16 years after Hurricane Gilbert (1988) was sustained over the next decade. The forests have not been significantly disturbed by hurricanes since 1988 (Tanner et al., 2014) and a period without major disturbance, during which forest canopies reformed, might retard the rate of invasion (Murphy and Metcalfe, 2016). However, since $P$. undulatum is shade-tolerant (Gleadow et al., 1983; Chai et al., 2012), this need not be so (Martin et al., 2009). Our long-term data allowed us to evaluate how diversity and richness of native tree species have been affected by invasion at local and wider scales. 


\section{Methods}

\subsection{Study sites}

The study sites are in upper montane rain forests in the western Blue Mountains of Jamaica (Fig. 1). A 40-year record of change derives from localised sites on and near the main ridge $\left(18^{\circ} 05^{\prime} \mathrm{N} ; 76^{\circ}\right.$ 39'W, 1540-1620 m elevation; four sites, 'Col' 0.09 ha, 'Mor' 0.06 ha, 'Mull' 0.10 ha and 'Slope' 0.10 ha; Tanner, 1977), measured in 1974, 1984, 1989, 1991, 1994, 2004, 2009, and 2014. The 24-year record of change derives from 16 systematically placed, widespread $200 \mathrm{~m}^{2}$ plots within c. 250 ha: six on the ridge crest, five on the northern slopes (windward to the prevailing trade winds), and five on the southern leeward slopes ( $18^{\circ} 05^{\prime} \mathrm{N} ; 76^{\circ} 39-40^{\prime} \mathrm{W}, 1375-1920 \mathrm{~m}$; Bellingham, 1991), measured in 1990, 1994, 2004, and 2014. Stem densities and tree species richness and diversity were measured (Table 1). In the localised sites and widespread plots, all stems $\geq 3 \mathrm{~cm}$ diameter at 1.3 $m$ height (dbh) were identified to species, tagged with a unique number, their diameter recorded, and a band painted at the dbh datum. At each remeasurement, all stems were relocated and their new dbh recorded. Dead stems were recorded and stems that had grown to become $\geq 3 \mathrm{~cm} d b h$ at each remeasurement were identified to species, tagged, and painted. Across all measurements, there was a total of 3012 stems in the localised sites, including those that died and those newly recruited (on average 1802 live stems at each measurement) and 2682 stems across the widespread plots (on average 1876 live stems). Concentrations of total carbon (C), N, and phosphorus ( $P$ and Bray-extractable P) were determined from soils collected in 2004 from each widespread plot (0-15 cm depth; Bellingham et al., 2005). Plot elevations were estimated from maps and GPS data.

The mean annual rainfall averages $2500-3000 \mathrm{~mm}$, and the mean maximum monthly temperatures range from 18.5 to $20.5{ }^{\circ} \mathrm{C}$ and minima from 11 to $12{ }^{\circ} \mathrm{C}$ (Kapos and Tanner, 1985). Our study sites were affected strongly by Hurricane Gilbert on 12 September 1988 (Bellingham et al., 1995). No other hurricane eye passed within $50 \mathrm{~km}$ of the study sites during 37 years before Hurricane Gilbert, and none have since; those with tracks >50 km away between 1988 and 2014 have not had strong 
effects (Tanner et al., 2014). Our study sites provide records of change in the forests for 14 years before and 26 years after Hurricane Gilbert in the localised sites, and a 24-year record (all postHurricane Gilbert) from the widespread plots.

\subsection{Analysis}

We determined whether tree and tree fern species were endemic (data from Adams (1972) and Proctor (1985), both updated by http://www.theplantlist.org/; access date 16 February 2017). We conducted rarefaction of stems in each plot based upon the fewest stems in a plot in a census (Ecosim; Gotelli and Enstminger, 2006) before calculating, for each of the widespread plots in 1990 and 2014, species richness, Shannon $\mathrm{H}^{\prime}$ and Fisher's alpha diversity (Magurran, 2003). We calculated all ANOVAs and linear regressions in GenStat ( $14^{\text {th }}$ edition). No data transformations were necessary for ANOVAs to account for heteroskedasticity. To determine whether there were differences in beta diversity across the widespread plots, we tested for differences using PERMDISP2 (implemented in the $\mathrm{R}$ package vegan (function betadisper) in $\mathrm{R}$ version 3.3.2) based on stem densities and basal areas of each tree species in each plot at each measurement between 1990 and 2014. We first determined whether there were differences in the centroids in multivariate analyses (there were none: $\mathrm{P}>0.99$ for both stem and basal area analyses, including all 16 plots in both 1990 and 2014). We then evaluated whether the average distances of the 16 plots from the centroid differed among years ( $\mathrm{F}$ value), with a $\mathrm{P}$ value calculated by permuting distances among the groups of plots (Anderson, 2006). We present an ordination of vegetation in the 16 widespread plots in 2014. Nonmetric multidimensional scaling with Jaccard distance was used to ordination the basal area data; we overlay vectors of variables correlated with the ordination. We calculated correlation using the envfit function from $R$ package vegan.

\section{Results}


By 2014, Pittosporum undulatum occurred in 12 of the 16 widespread plots (75\%), and comprised, on average, $11.9 \%$ of stems and $10.4 \%$ of the basal area (Fig. 2), an increase of $3.2 \%$ and $4.7 \%$ respectively since 2004, with both variables showing near-linear rates of increase from low levels of invasion in 1990, soon after Hurricane Gilbert. The four localised sites studied since 1974 were much less invaded in 2014; the Mull site was the most invaded (3.0\% of the basal area, Fig. 2). Across the widespread plots, the combined basal area of all species increased significantly by $9.7 \%$ between 1990 and 2014, due nearly entirely to a 526\% increase in $P$. undulatum basal area, since the basal area of all other species (and the subset that are endemic) was unchanged (Table 1). In contrast, the combined stem density of all species was unchanged between 1990 and 2014, but $P$. undulatum stem densities increased by $500 \%$ while the stem densities of all other species declined by $13.6 \%$ (Table 1 ). Endemic woody species richness per plot declined by $13.5 \%$ over the 24 -year period, and their stem densities by $17.6 \%$ (Table 1 ). Shannon $\mathrm{H}^{\prime}$ and Fisher's alpha diversity of all woody species per plot did not change significantly (Table 1).

Across the widespread plots, however, the greater the increase in the basal area of $P$. undulatum over 24 years the greater the decline in local, plot-scale tree species diversity (Shannon $\mathrm{H}^{\prime}$ and Fisher's alpha) and richness, even after removing from the analysis an outlier highly-invaded plot with substantially the greatest increase in P. undulatum basal area (Fig. 3a-c). The percentage of stems of endemic tree species also declined over 24 years the more $P$. undulatum basal areas increased (Fig. 3d), as did the number of endemic stems per plot $\left(r^{2}=0.35, P=0.009\right.$; data not shown). Declines in tree species diversity ( $\mathrm{H}^{\prime}$ and Fisher's alpha), richness, and in the percentage of endemic trees were most apparent where the basal area of $P$. undulatum increased $>0.2 \mathrm{~m}^{2} \mathrm{ha}^{-1} \mathrm{yr}^{-1}$ over 24 years (Fig. 3). There were no differences, among any of these variables, in whether the greatest declines occurred in plots on the northern or southern slopes or the ridge crest. Among 
relationships between the 2014 basal area of $P$. undulatum and the 1990 native tree species richness or diversity $\left(\mathrm{H}^{\prime}\right.$ and Fisher's alpha; all $\left.\mathrm{P}>0.11\right)$.

There were no significant differences in beta diversity across the 16 widespread plots between 1990 and 2014, in terms of both basal area $(F=0.0007, P=0.98)$ and stem density $(F=0.220, P=0.64)$. Among the 16 plots, tree species composition as expressed by basal area in 2014 was driven most strongly by elevation, and also by soil $\mathrm{C}$ and $\mathrm{N}$ concentrations (Fig. 4). Centroids of plots on the windward northern slopes did not differ significantly from those on the leeward southern slopes $(F=$ 1.29, $\mathrm{P}=0.13$; Fig. 4).

Annual increases in basal area of $P$. undulatum across the widespread plots were greater the lower the soil $\mathrm{N}$ concentration (Fig. $5 \mathrm{a}$ ) and the lower the soil $\mathrm{C}$ concentration (Fig. 5b). They were not elevation.

\section{Discussion}

Invasion by Pittosporum undulatum of Jamaican montane rain forests over c. 25 years increased at a near-linear rate, with no sign of the rate slowing as forest canopies closed during recovery after intense hurricane disturbance in 1988. By 2014, P. undulatum comprised, on average, c. $10 \%$ of the stems and the basal area across the widespread plots. Its dominance is likely to continue to increase because, in the most invaded of the widespread plots, $P$. undulatum comprised $72 \%$ of total stems and $58 \%$ of the total basal area in 2014. There was no evidence, from the small sample of plots $(\mathrm{n}=$ 8) initially uninvaded but invaded subsequently, of any relationship between invasion success and initial in situ native woody species richness. This contrasts with Puerto Rican forests, where the greater the native tree species richness the less the likelihood of non-native plant invasion 
"ruderal" species, whereas $P$. undulatum has attributes, notably shade-tolerance, that make it likely to be a long-persistent invader of forests (Martin et al., 2009), irrespective of local tree species richness (Fridley et al., 2007; Stohlgren et al., 2006).

Seeds of $P$. undulatum are bird-dispersed, like those of many non-native trees in tropical montane forests (Binggeli and Hamilton, 1993; Huenneke and Vitousek, 1990; Meyer, 1996), and native Jamaican birds are likely to have dispersed seeds throughout the forests, resulting in an advance regeneration of established seedlings. Intense hurricanes are more likely as a result of climate change (Knutson et al., 2010). Each time intense hurricanes occur, the canopy defoliation and treefall gaps they cause will accelerate the growth of established $P$. undulatum seedlings to become mature trees, as happened after Hurricane Gilbert, boosting invasion into forests where mature $P$. undulatum trees are currently scarce (Bellingham et al., 2005; Murphy and Metcalfe, 2016). The invasion by the non-native tree Bischofia javanica Blume (Phyllanthaceae) in subtropical forests on Hahajima (Ogasawara Islands, Japan) has close parallels. Like $P$. undulatum, its seeds are birddispersed and its seedlings are shade-tolerant (Yamashita et al., 2003), yet grow rapidly in response to increased light (Yamashita et al., 2000). An intense typhoon in 1983 accelerated its rate of invasion and it is now dominant in many areas (Fukasawa et al., 2009).

The decline in Jamaican native tree species diversity ( $\mathrm{H}^{\prime}$ and Fisher's alpha) and richness over 24 years up to 2014 the more $P$. undulatum gained in dominance provides more compelling evidence than trends a decade earlier (Bellingham et al., 2005). These declines have parallels with the consequences of invasions of non-native trees, especially Psidium cattleianum Afzel. ex Sabine

211 (Myrtaceae), in tropical forests in Mauritius. At one site in these forests, native trees species richness

212 (stems $\geq 1 \mathrm{~cm} \mathrm{dbh}$ ) declined over 21-27 years as the stem density of non-native trees increased 213 (Florens et al. 2017). Since stem radial growth rates of $P$. undulatum are 4-5 times greater than 214 native Jamaican tree species (Bellingham et al., 2005), $P$. undulatum probably reduced local-scale species richness and diversity by niche pre-emption (Catford et al., 2012; Denslow, 2003), 
exploitative competition (Catford et al., 2012; Malizia et al., 2017), or both. It may also exert interference competition through potentially allelopathic effects (Gleadow and Ashton, 1981). Although native species richness and diversity declined at a plot scale, there is no evidence so far that the forests are becoming more homogeneous because of $P$. undulatum invasion, i.e. there was no significant reduction in beta diversity. So far, the forests remain distinct along gradients of elevation (Asprey and Robbins, 1953) and soil C and N concentrations (Tanner 1977).

Forests dominated by $P$. undulatum are widespread on the southern, leeward slopes of the western Blue Mountains (McDonald et al., 2003) and along edges of the Port Royal Mountains further west. Many of these forests developed through secondary succession on land cleared for coffee plantations between 1790 and 1834 and later abandoned (Chai and Tanner, 2011), and, since then, on abandoned small-scale cultivations (McDonald and Healey, 2000). A point-in-time assessment conducted now might infer that $P$. undulatum has been dominant throughout succession but our study shows this need not be so because native tree richness and diversity declined while $P$. undulatum increased in dominance in these successional forests over 24 years.

Declining native tree species richness and diversity at a plot-scale as $P$. undulatum invades Jamaican forests provides further evidence that island ecosystems are particularly susceptible to non-native plant invasions (Pyšek et al., 2012). Since Jamaican montane forests are an international hotspot of endemism (Myers et al., 2000), the decline in endemic tree species over 24 years at a plot scale is especially concerning. Local declines of endemic species, as shown in Jamaica, represent the first stage of invasion effects that could ultimately lead to their extinction (Downey and Richardson, 2016).

While our study focused on relationships between $P$. undulatum invasion and tree diversity, the diversity of other native plants may also be affected. Pittosporum undulatum has a dense canopy that reduces light intensity, which, in Australia, can suppress nearly all understorey plants (Gleadow and Ashton, 1981). We lack data from Jamaica to determine whether understorey seedlings, as well 

suppressed. Epiphytes are prominent in Jamaican montane forests (Asprey and Robbins, 1953; Grubb and Tanner, 1976), but nearly all the $P$. undulatum trees we measured, even large individuals, lack trunk and branch epiphytes. Epiphytic bromeliads are common on many native tree species (Grubb and Tanner, 1976) but are absent from $P$. undulatum. Growing dominance of forests by $P$. undulatum, hence fewer epiphytic bromeliads, is in turn likely to affect other species; e.g. bromeliads are key foraging sites for the endangered endemic Jamaican blackbird (Nesopsar nigerrimus Osburn (Icteridae); Cruz, 1978), which has its greatest population densities in the Blue Mountains (Varty, 1991). The negative effects of the $P$. undulatum invasion on forest epiphyte abundance are also likely to affect other ecosystem functions. Trunk and canopy epiphytes, and the arboreal soils that they support, play a prominent role in nutrient cycling and the hydrology of montane forests (Gotsch et al., 2016; Ah-Peng et al., 2017). Studies are needed, comparing forests highly invaded and uninvaded by $P$. undulatum, on the consequences for forest hydrology of the reduction in arboreal soils and interception of stem flow by trunk epiphytes.

Hurricanes are a long-term selection pressure on Jamaican forests, yet the apparent resilience of the montane forests' basal area after an intense hurricane in 1988 masks a significant shift in its composition. Although the loss of overall forest basal area caused by the hurricane (Bellingham et al., 1995) recovered over the next 26 years, it nearly entirely comprised $P$. undulatum (Table 1 ). It is unclear whether this compositional shift altered other forest ecosystem properties. Tree growth in tropical montane forests is limited not only by low light levels but also low soil nutrient concentrations (Bruijnzeel et al., 2010; Dalling et al., 2016; Tanner et al., 1998). In montane rain forests on Hawai'i, N limits tree growth, and the non-native invasive tree Psidium cattleianum has greater N-use efficiency than the dominant native tree Metrosideros polymorpha Gaudich. (Myrtaceae) (Funk and Vitousek, 2007). In Jamaican montane forests, its relationships with soil C and $\mathrm{N}$ concentrations suggest that invasion by $\mathrm{P}$. undulatum proceeded more rapidly in plots where their concentrations were lowest. However, soil $\mathrm{C}$ and $\mathrm{N}$ were sampled in invaded and uninvaded plots 
and it is unknown whether low soil $\mathrm{N}$ concentrations, especially in plots with rapid increases in $P$. undulatum, resulted from depletion of soil $\mathrm{N}$ by this tree. Similarly, if rates of accumulation of soil organic matter are low in invaded forests, then low soil $\mathrm{C}$ concentrations could be a consequence of invasion. Moreover, forests with very high soil $\mathrm{C}$ concentrations do not restrict $P$. undulatum invasion. Forests in Mor sites have $95 \%$ soil organic matter content and pH 3.6 in the top $10 \mathrm{~cm}$ (Tanner, 1977), and have very low tree diversity because most native trees cannot establish in the soils (Sugden et al., 1985). However, P. undulatum is now invading Mor sites (Fig. 2; Wardle et al., 2015) and may cause changes to the soil that further accelerates its invasion through a positive feedback process. Plant-soil feedbacks are well recognised as processes that accompany invasions by non-native trees (Ehrenfeld, 2010; Vitousek and Walker, 1989; Wardle and Peltzer, 2017). Increasing dominance of $P$. undulatum may have consequences for ecosystem services such as nutrient cycling and soil formation if such feedbacks occur, and potentially for other services such as water cycling, regulation of water flows, and erosion control. The resilience of forests dominated by P. undulatum to natural disturbances, such as hurricanes and earthquakes, is unknown. protected areas, including the Blue and John Crow Mountains National Park (Chai et al., 2009). However, simply maintaining the area of forest cover will be insufficient to protect biodiversity because there have been clear declines in its native tree diversity at a plot scale as a non-native tree has invaded. Native birds disperse $P$. undulatum seeds to remote locations within the National Park so it seems inevitable that the effects we have shown will become more widespread if the invasion proceeds unchecked. An option could be to eliminate the large propagule pressure from forests dominated by $P$. undulatum along the National Park's southern borders, but the resulting deforestation on steep, erosion-prone slopes could be disastrous for local farmers, because of landslides and sedimentation (Barker and McGregor, 1988), and for ensuring water supplies (including to the capital, Kingston). It would be prudent to embark now upon remedial action to 
with greatest endemism and safeguarding these against invasion by a continuing programme of physical removal of $P$. undulatum and its chemical control (currently drilling and injecting mature trees with glyphosate during the dry season; Susan Otuokon, pers. comm.). The distinct crown architecture of $P$. undulatum and the strong infra-red reflectance of its leaves mean that it can be distinguished by remote sensing, which could identify areas invaded by adult trees for control (Goodland and Healey, 1997), although extensive ground surveys are also needed to determine the spatial extent and abundance of seedlings and saplings below native canopies that also require control. In rain forests on Hawai'i, high-resolution airborne imaging spectroscopy determined combinations of substrate type and elevation most susceptible to invasion by a non-native tree, Psidium cattleianum (Barbosa et al., 2017). The same technology might be suitable for identifying areas in which to focus control efforts and those most meriting protection against invasion by $P$. undulatum in the topographically and geologically complex Blue Mountains. Biological control seems a suitable option for $P$. undulatum because it is so widespread in the Blue Mountains and it has no closely related Jamaican species. While there are no current options for the biological control of $P$. undulatum (Pasiecznik and Rojas-Sandoval, 2015), this might be a focus for further research because it is invasive in many countries.

The outstanding cultural and natural heritage of the Blue and John Crow Mountains National Park resulted in its being declared a UNESCO World Heritage site in 2015. The Jamaican Government administers the National Park, secures its boundaries, and manages tourism within it. The National Park's managers may require international assistance to address the chronic degradation of the forests caused by long-term invasion by $P$. undulatum and other non-native plants.

\section{Acknowledgements}


Thanks are due to these authorities in Jamaica: (i) the Heads of the Department of Forestry in the Ministry of Agriculture, and the Park Managers of the Blue and John Crow Mountains National Park for permission to undertake the study; (ii) the Directors of the Botanic Gardens Division of the Ministry of Agriculture for permission to use the Cinchona Botanic Gardens as a field station; (iii) G. H. Sidrak, L. B. Coke, P. V. Devi Prasad, R. Robinson, D. Webber. E. Hyslop, M. Webber, J. Cohen and K. McLaren of the Department of Botany (more recently Life Sciences) of the University of the West Indies for assistance and facilities. Hannah Scrase and Pierre Binggeli provided valuable field assistance. Shauna-Lee Chai and Susan Otuokon provided valuable information. PJB received support from the British Ecological Society [research grant 4709/5747] and from New Zealand's Ministry for

\section{References}

Ackerman, J.D., Tremblay, R.L., Rojas-Sandoval, J., Hernández-Figueroa, E., 2017. Biotic resistance in the tropics: patterns of seed plant invasions within an island. Biol. Invasions 19, 315-328.

Adams, C.D., 1972. Flowering Plants of Jamaica. University of the West Indies, Mona. T.A.J., 2017. The role of epiphytic bryophytes in interception, storage, and the regulated release of atmospheric moisture in a tropical montane cloud forest. J. Hydrol. 548, 665-673. 62, 245-253. 
Asprey, G.F., Robbins, R.G., 1953. The vegetation of Jamaica. Ecol. Monog. 23, 359-412.

Barbosa, J.M., Asner, G.P., Hughes, R.F., Johnson, M.T., 2017. Landscape-scale GPP and carbon density inform patterns and impacts of an invasive tree across wet forests of Hawaii. Ecol. Appl. 27, 403-415.

Barker, D., McGregor, D.F.M., 1988. Land degradation in the Yallahs Basin, Jamaica: historical notes and contemporary observations. Geography 73, 116-124.

Bellingham, P.J., 1991. Landforms influence patterns of hurricane damage: evidence from Jamaican montane forests. Biotropica 23, 427-433.

Bellingham, P.J., Tanner, E.V.J., Healey, J.R., 1995. Damage and responsiveness of Jamaican montane tree species after disturbance by a hurricane. Ecology 76, 2562-2580.

Bellingham, P.J., Tanner, E.V.J., Healey, J.R., 2005. Hurricane disturbance accelerates invasion by the alien tree Pittosporum undulatum in Jamaican montane rain forests. J. Veg. Sci. 16, 675-684.

Binggeli, P., Hamilton, A.C., 1993. Biological invasion by Maesopsis eminii in the East Usambara forests, Tanzania. Opera Bot. 121, 229-235.

Bruijnzeel, L.A., Scatena, F.N., Hamilton, L.S. (eds.), 2010. Tropical Montane Cloud Forests: Science for Conservation and Management. Cambridge University Press, Cambridge.

Catford, J.A., Daehler, C.C., Murphy, H.T., Sheppard, A.W., Hardesty, B.D., Westcott, D.A., Rejmánek, M., Bellingham, P.J., Pergl, J., Horwitz, C.C., Hulme, P.E., 2012. The intermediate disturbance hypothesis and plant invasions: implications for species richness and management. Perspect. Plant Ecol. Evol. Syst. 14, 231-241.

Chai, S.-L., Healey, J.R., Tanner, E.V.J., 2012. Evaluation of forest recovery over time and space using permanent plots monitored over 30 years in a Jamaican montane rain forest. PLoS One 7, e48859. 
Chai, S.-L., Tanner, E., McLaren, K., 2009. High rates of forest clearance and fragmentation pre- and post-National Park establishment: the case of a Jamaican montane rainforest. Biol. Conserv. 142, 484-2492.

Chai, S.-L., Tanner, E.V.J., 2011. 150-year legacy of land use on tree species composition in oldsecondary forests of Jamaica. J. Ecol. 99, 113-121.

Cruz, A., 1978. Adaptive evolution in the Jamaican Blackbird Nesopsar nigerrimus. Ornis Scand. 9, $130-137$.

Dalling, J.W., Heineman, K., González, G., Ostertag, R., 2016. Geographic, environmental and biotic sources of variation in the nutrient relations of tropical montane forests. J. Trop. Ecol. 32, 368-383.

Dawson, W., Burslem, D.F.R.P., Hulme, P.E., 2015. Consistent effects of disturbance and forest edges on the invasion of a continental rain forest by alien plants. Biotropica $47,27-37$.

Denslow, J.S., 2003. Weeds in paradise: thoughts on the invasibility of tropical islands. Ann. Missouri Bot. Gard. 90, 119-127.

Denslow, J.S., DeWalt, S.J., 2008. Exotic plant invasions in tropical forests: patterns and hypotheses. In: Carson, W.P., Schnitzer, S.A. (eds.) Tropical Forest Community Ecology. Blackwell, Oxford, pp 409-426.

Dillis, C., Marshall, A.J., Rejmánek, M., 2017. Change in disturbance regime facilitates invasion by Bellucia pentamera Naudin (Melastomataceae) at Gunung Palung National Park, Indonesia. Biol. Invasions 19, 1329-1337.

Downey, P.O., Richardson, D.M., 2016. Alien plant invasions and native plant extinctions: a sixthreshold framework. AoB Plants 8, plw047. $59-80$. 

of vegetation structure and ecosystem function. J. Trop. Ecol. 32, 355-367.

Fine, P.V.A., 2002. The invasibility of tropical forests by exotic plants. J. Trop. Ecol. 18, 687-705.

Florens, F.B.V., Baider, C., Martin, G.M.N., Seegoolam, N.B., Zmanay, Z., Strasberg, D., 2016. Invasive alien plants progress to dominate protected and best preserved wet forests of an oceanic island. J. Nat. Conserv. 34, 93-100.

Florens, F.B.V., Baider, C., Seegoolam, N.B., Zmanay, Z., Strasberg, D., 2017. Long-term declines of native trees in an oceanic island's tropical forests invaded by alien plants. Appl. Veg. Sci. 20, 94-105.

Fridley, J.D., Stachowicz, J.J., Naeem, S., Sax, D.F., Seabloom, E.W., Smith, M.D., Stohlgren, T.J., Tilman, D., Von Holle, B., 2007. The invasion paradox: reconciling pattern and process in species invasions. Ecology 88, 3-17.

Fukasawa, K., Koike, F., Tanaka, N., Otsu, K., 2009. Predicting future invasion of an invasive alien tree in a Japanese oceanic island by process-based statistical models using recent distribution maps. Ecol. Res. 24, 965-975.

Funk, J.L., Vitousek, P.M., 2007. Resource-use efficiency and plant invasion in low-resource systems. Nature 446, 1079-1081.

Funk, J.L., 2013. The physiology of invasive plants in low-resource environments. Conservation Physiology 1, 10.1093/conphys/cot026 Victoria. I. Invasion patterns and plant morphology. Aust. J. Bot. 29, 705-720. 
Gotelli, N.J., Entsminger, G.L., 2006. Ecosim: Null Models Software for Ecology, Version 7. Acquired Intelligence Inc. and Kesey-Bear, Jericho, Vermont. tropical montane cloud forests. J. Trop. Ecol. 32, 455-468.

Grubb, P.J., Tanner, E.V.J., 1976. The montane forests and soils of Jamaica: a reassessment. J. Arnold Arb. 57, 313-368.

Grubb, P.J., Bellingham, P.J., Kohyama, T.S., Piper, F.I., Valido, A., 2013. Disturbance regimes, gapdemanding trees and seed mass related to tree height in warm temperate rain forests worldwide. Biol. Rev. Camb. Philos. Soc. 88, 701-744. cattleianum: implications for management of native Hawaiian forests. Biol. Conserv. 53, 199-211. $66,241-250$. Srivastava, A.K., Sugi, M., 2010. Tropical cyclones and climate change. Nature Geoscience 3, 157163. global comparison of plant invasions on oceanic islands. Perspect. Plant Ecol. Evol. Syst. 12, 145-161. 

indigenous to the montane forest of the Blue Mountains, Jamaica for reforestation and agroforestry. For. Ecol. Manage. 175, 379-401.

Magurran, A.E., 2003. Measuring Biological Diversity. Wiley-Blackwell, Oxford.

Malizia, A., Osinaga-Acosta, O., Powell, P.A., Aragón, R., 2017. Invasion of Ligustrum lucidum native trees. J. Veg. Sci., in press, doi: 10.1111/jvs.12572.

Martin, P.H., Bellingham, P.J., 2016. Towards integrated ecological research in tropical montane cloud forests. J. Trop. Ecol. 32, 345-354.

Martin, P.H., Sherman, R.E., Fahey, T.J., 2004. Forty years of tropical forest recovery from agriculture: structure and floristics of secondary and old growth riparian forests in the Dominican Republic. Biotropica 36, 297-317.

Martin, P.H., Canham, C.D., Marks, P.L., 2009. Why forests appear resistant to exotic plant invasions: intentional introductions, stand dynamics, and the role of shade tolerance. Front. Ecol. Environ. 7, $442 \quad 142-149$.

Meyer, J.-Y., 1996. Status of Miconia calvescens (Melastomataceae), a dominant invasive tree in the Society Islands, French Polynesia. Pac. Sci. 50, 66-76.

Murphy, H.T., Metcalfe, D.J., 2016. The perfect storm: weed invasion and intense storms in tropical forests. Austral Ecol. 41, 864-874. hotspots for conservation priorities. Nature 403, 853-858. 
Proctor, G.R., 1985. Ferns of Jamaica. British Museum (Natural History), London.

Pyšek, P., Jarošík, V., Hulme, P.E., Pergl, J., Hejda, M., Schaffner, U., Vilà, M., 2012. A global assessment of invasive plant impacts on resident species, communities and ecosystems: the interaction of impact measures, invading species' traits and environment. Global Change Biol. 18, $1725-1737$.

Rojas-Sandoval, J., Tremblay, R.L., Acevedo-Rodríguez, P., Díaz-Soltero, H., 2017. Invasive plant species richness in the West Indies: geographical, ecological, and floristic insights. Ecol. Evol. 7, $4522-4533$.

Shreve, F., 1914. A montane rain-forest. A contribution to the physiological plant geography of Jamaica. Carnegie Institute of Washington Publication No. 199, Washington, DC.

Silva, L.B., Teixeira, A., Alves, M., Elias, R.B., Silva, L., 2017. Tree age determination in the widespread woody plant invader Pittosporum undulatum. For. Ecol. Manage. 400, 457-467. of biotic acceptance. Preselia 78, 405-426.

Sugden, A.M., Tanner, E.V.J., Kapos, V., 1985. Regeneration following clearing in a Jamaican montane forest: results of a ten year study. J. Trop. Ecol. 1, 329-351.

Tanner, E.V.J., 1977. Four montane rain forests of Jamaica: a quantitative characterization of the floristics, the soils and the foliar nutrient levels, and a discussion of the interrelations. J. Ecol. 65, 883-918.

471 Thompson, D.A., Bretting, P.K., Humphries, M. (eds.) Forests of Jamaica. Jamaican Society of 472 Scientists and Technologists, Kingston, pp 15-30. 
473 Tanner, E.V.J., Vitousek, P.M., Cuevas, E., 1998. Experimental investigation of nutrient limitation of

474 forest growth on wet tropical mountains. Ecology 79, 10-22.

475 Tanner, E.V.J., Rodriguez-Sanchez, F., Healey, J.R., Holdaway, R.J., Bellingham, P.J., 2014. Long-term 476 hurricane damage effects on tropical forest tree growth and mortality. Ecology 95, 2974-2983.

477 van Wilgen, B.W., Reyers, B., Le Maitre, D.C., Richardson, D.M., Schonegevel, L., 2008. A biome-scale assessment of the impact of invasive alien plants on ecosystem services in South Africa. J. Environ. Manage. 89, 336-349.

Varty, N., 1991. The status and conservation of Jamaica's threatened and endemic forest avifauna and their habitats following Hurricane Gilbert. Bird Conserv. International 1, 135-151.

Vitousek, P.M., Walker, L.R., 1989. Biological invasion by Myrica faya in Hawai'i: plant demography, nitrogen fixation, ecosystem effects. Ecol. Monog. 59, 247-265.

Wardle, D.A., Bellingham, P.J., Kardol, P., Giesler, R., Tanner, E.V.J., 2015. Coordinated aboveground and belowground responses to local-scale soil fertility differences among two contrasting Jamaican rain forest types. Oikos $124,285-297$.

Wardle, D.A., Peltzer, D.A., 2017. Impacts of invasive biota in forest ecosystems in an abovegroundbelowground context. Biol. Invasions: in press, doi 10.1007/s10530-017-1372-x. favoring an invasive over native trees in subtropical islands, Japan. Oecologia 125, 412-419. invasive and native trees of subtropical Pacific islands. J. Veg. Sci. 14, 15-24. 
493

494

495

496

497

498

499

500

501

Table 1. Basal area and stem density (mean \pm SEM) across 16 widespread plots in tropical montane rain forests in Jamaica in 4 measurement years, with all woody species other than Pittosporum undulatum (all are native species except for Cinchona officinalis L. (Rubiaceae) in one plot), endemic woody species, $P$. undulatum alone, and all species combined, along with species richness per 200 $\mathrm{m}^{2}$ plot of woody species other than $P$. undulatum, and of endemic woody species, and Shannon $\mathrm{H}^{\prime}$ and Fisher's alpha (the latter two computed after rarefaction based on the fewest stems per plot at any measurement); for significant differences $(P<0.05)$ determined by repeat-measures ANOVA ( $F$ and $P$ statistics tabulated), post-hoc differences were determined by paired t-tests (shared letters denote no significant differences between years, $\mathrm{P}>0.05$ ).

\begin{tabular}{|c|c|c|c|c|c|c|}
\hline & 1990 & 1994 & 2004 & 2014 & $F$ & $P$ \\
\hline \multicolumn{7}{|l|}{ Basal area $\left(\mathrm{m}^{2} \mathrm{ha}^{-1}\right)$} \\
\hline Non-P. undulatum & $49.24 \pm 3.97$ & $49.17 \pm 4.05$ & $48.91 \pm 4.30$ & $49.36 \pm 4.75$ & 0.02 & 0.906 \\
\hline Endemic woody & $15.45 \pm 2.55$ & $15.17 \pm 2.49$ & $15.10 \pm 2.44$ & $15.85 \pm 2.58$ & 0.43 & 0.560 \\
\hline \multicolumn{7}{|l|}{ species } \\
\hline P. undulatum & $0.49 \pm 0.39^{a}$ & $0.94 \pm 0.68^{a}$ & $2.78 \pm 1.30^{b}$ & $5.19 \pm 1.97^{c}$ & 8.16 & 0.011 \\
\hline \multirow[t]{2}{*}{ All species } & $49.72 \pm 3.98$ & $50.11 \pm 4.06$ & $51.69 \pm 4.12$ & $54.55 \pm 4.26$ & 6.91 & 0.009 \\
\hline & a & a & a & $\mathrm{b}$ & & \\
\hline \multicolumn{7}{|l|}{ Stems ha ${ }^{-1}(\geq 3 \mathrm{~cm}$} \\
\hline \multicolumn{7}{|l|}{ dbh) } \\
\hline Non-P. undulatum & $5669 \pm 549^{a}$ & $5606 \pm 530^{a}$ & $5266 \pm 527^{a}$ & $4897 \pm 550^{b}$ & 4.29 & 0.048 \\
\hline Endemic woody & $2278 \pm 302^{\mathrm{a}}$ & $2188 \pm 301^{a b}$ & $1988 \pm 311^{b c}$ & $1878 \pm 323^{c}$ & 4.42 & 0.038 \\
\hline \multicolumn{7}{|l|}{ species } \\
\hline P. undulatum & $144 \pm 118^{a}$ & $322 \pm 225^{a}$ & $681 \pm 348^{b}$ & $863 \pm 425^{c}$ & 5.05 & 0.038 \\
\hline All species & $5813 \pm 588$ & $5928 \pm 608$ & $5947 \pm 629$ & $5759 \pm 619$ & 0.93 & 0.406 \\
\hline Non-P. undulatum & $23.4 \pm 1.6$ & $22.9 \pm 1.6$ & $22.6 \pm 1.6$ & $21.1 \pm 1.6$ & 2.96 & 0.091 \\
\hline \multicolumn{7}{|l|}{ woody species } \\
\hline richness per $200 \mathrm{~m}^{2}$ & & & & & & \\
\hline
\end{tabular}




$\begin{array}{lcccccc}\text { Endemic tree woody } & 11.1 \pm 1.0^{\mathrm{a}} & 10.4 \pm 1.0^{\mathrm{b}} & 10.2 \pm 1.0^{\mathrm{ab}} & 9.6 \pm 1.0^{\mathrm{b}} & 4.08 & 0.030 \\ \text { species richness per } & & & & & & \\ & & & & & & \\ 200 \mathrm{~m}^{2} & & & & & & \\ \text { Shannon } \mathrm{H}^{\prime} & 2.7 \pm 0.1 & 2.7 \pm 0.1 & 2.7 \pm 0.1 & 2.6 \pm 0.1 & 1.45 & 0.249 \\ \text { Fisher's alpha } & 10.0 \pm 1.1 & 9.5 \pm 0.9 & 9.5 \pm 1.0 & 8.9 \pm 0.9 & 1.53 & 0.238\end{array}$

502

503

504 
Fig. 1. Location of the study sites (inset shows location within Jamaica). Symbols denote locations of

507 the widespread plots, and the boundary in both maps denotes the Blue and John Crow Mountains

508 National Park.

509 Fig. 2. The percentage of (A) basal area comprised by Pittosporum undulatum over 40 years in four localised sites and (B) basal area and stems comprised by $P$. undulatum across 16 widespread plots (mean + SEM) over 24 years in Jamaican montane rain forests; NB: Fig. 2a corrects an error in Bellingham et al. (2005), where the percentage basal area in the Col site in the 2004 measurement should have been higher than reported.

514 Fig. 3. Changes in tree diversity (A: Shannon H'; B: Fisher's alpha), tree species richness (C), and percentage endemic trees (D) per plot over 24 years (all calculated after rarefaction per plot on the census with fewest stems) in relation to annual change in basal area of Pittosporum undulatum across 16 widespread plots in Jamaican montane rain forests (regressions were calculated omitting the bracketed datum with large leverage; black circles = plots on northern slopes, white circles = ridge crest, triangles = southern slopes).

Fig. 4. Non-metric multidimensional scaling (NMDS) ordination of vegetation composition in widespread plots, based on basal area in 2014. Filled symbols indicate plots invaded by Pittosporum undulatum, unfilled symbols non-invaded plots on northern slopes, range crest, and southern slopes. Arrows indicate significant correlations between elevation, soil nitrogen $(\mathrm{N})$ and carbon $(\mathrm{C})$ concentrations with the ordinated vegetation.

Fig. 5. A: total soil nitrogen $(\mathrm{N})$ concentration $(\%)$ and $\mathrm{B}$ : total soil carbon $(\mathrm{C})$ concentration $(\%)$ in relation to annual change in basal area of Pittosporum undulatum across 16 widespread plots in Jamaican montane rain forests (regressions were calculated omitting the bracketed datum with 
528 large leverage; black circles = plots on northern slopes, white circles = ridge crest, triangles =

529 southern slopes). 


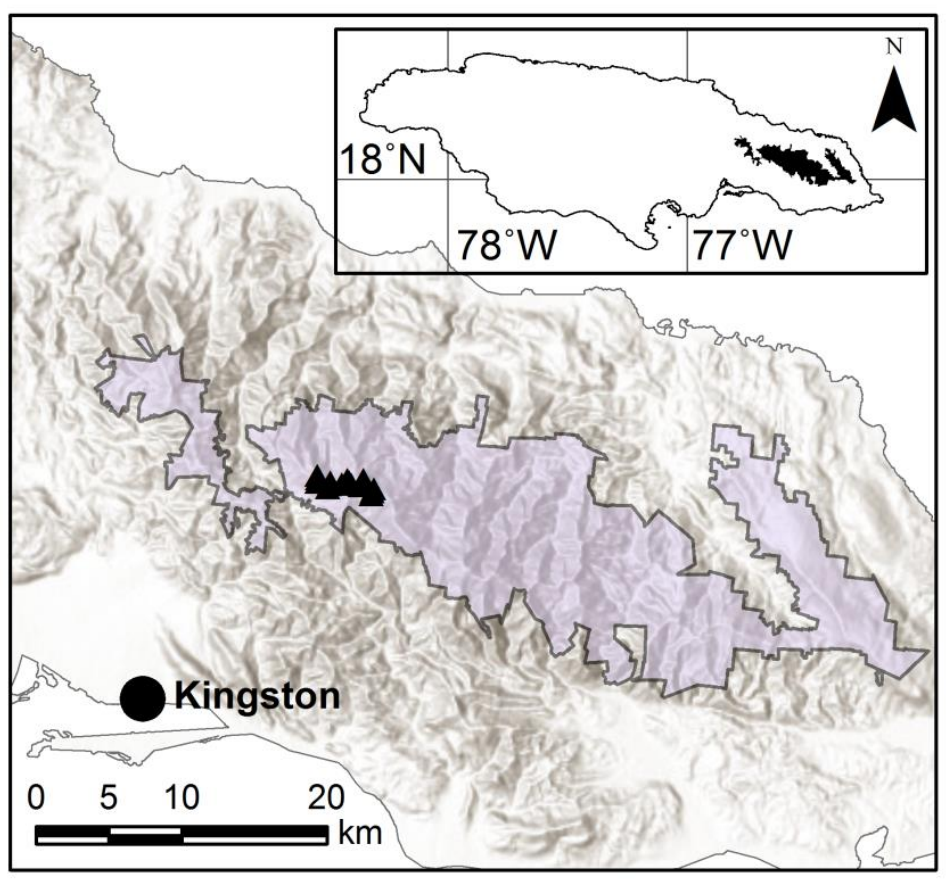

530

531 Fig. 1. Location of the study sites (inset shows location within Jamaica). Symbols denote locations of

532 the widespread plots, and the boundary in both maps denotes the Blue and John Crow Mountains

533 National Park. 

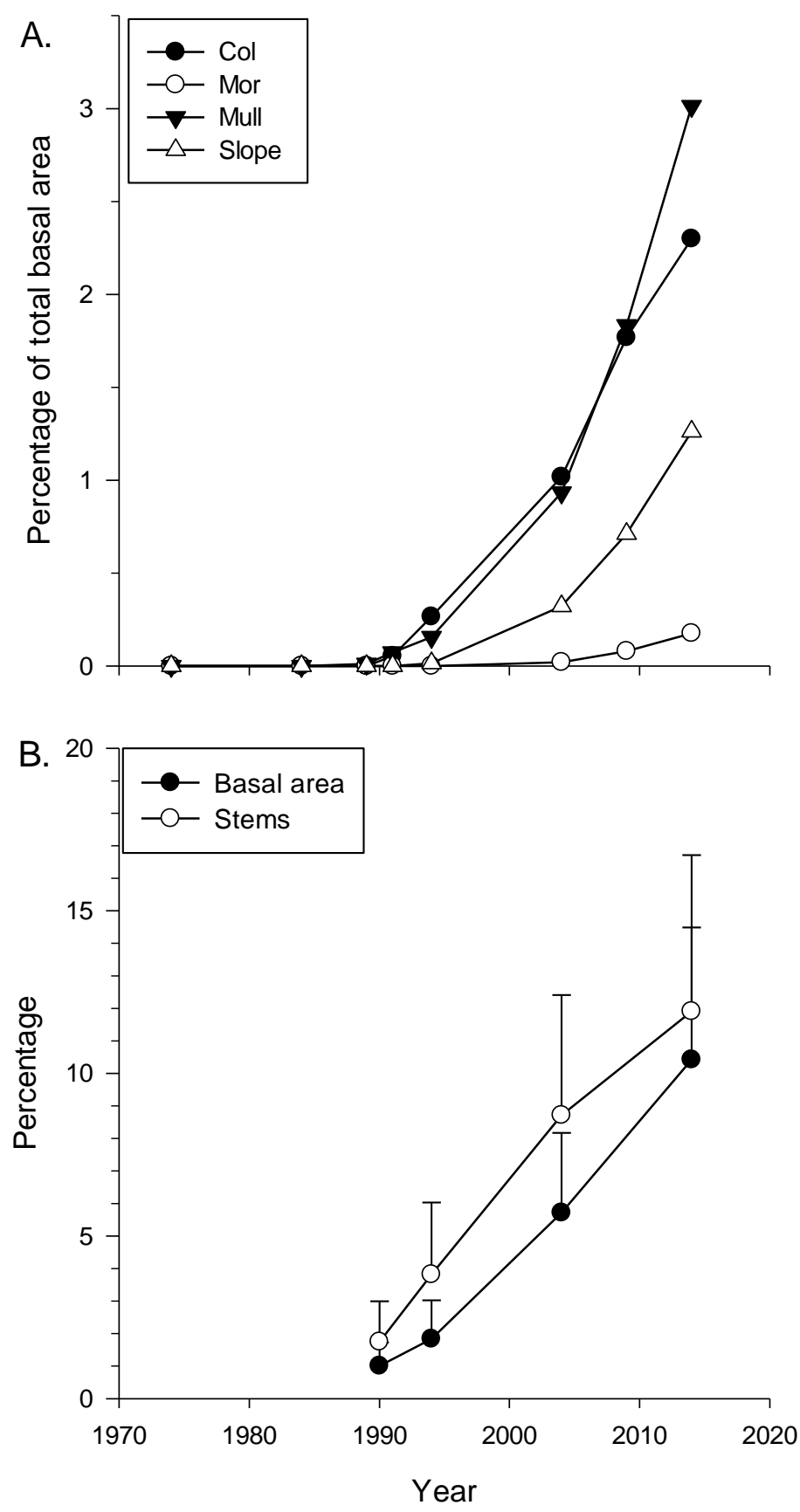

Fig. 2. The percentage of (A) basal area comprised by Pittosporum undulatum over 40 years in four

536 localised sites and (B) basal area and stems comprised by $P$. undulatum across 16 widespread plots

537 (mean + SEM) over 24 years in Jamaican montane rain forests; NB: Fig. 2a corrects an error in

538 Bellingham et al. (2005), where the percentage basal area in the Col site in the 2004 measurement

539 should have been higher than reported. 

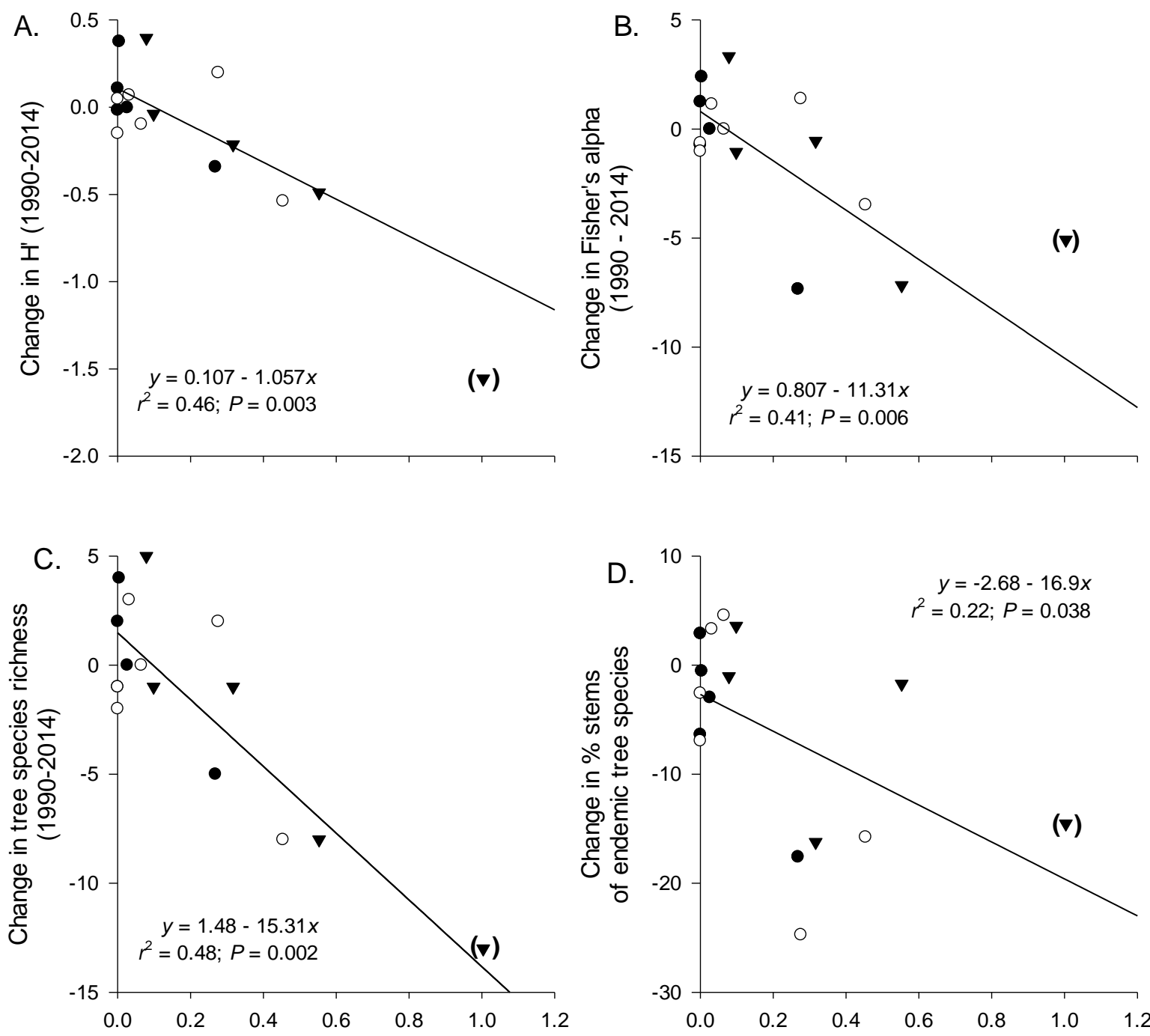

Change in Pittosporum undulatum basal area $\left(\mathrm{m}^{2} \mathrm{ha}^{-1} \mathrm{yr}^{-1}, 1990-2014\right)$

Change in Pittosporum undulatum basal area (m² $\left.\mathrm{ha}^{-1} \mathrm{yr}^{-1}, 1990-2014\right)$

Fig. 3. Changes in tree diversity (A: Shannon $\mathrm{H}^{\prime}$; B: Fisher's alpha), tree species richness (C), and

544 percentage endemic trees (D) per plot over 24 years (all calculated after rarefaction per plot on the

545 census with fewest stems) in relation to annual change in basal area of Pittosporum undulatum

546 across 16 widespread plots in Jamaican montane rain forests (regressions were calculated omitting

547 the bracketed datum with large leverage; black circles = plots on northern slopes, white circles = 548 ridge crest, triangles $=$ southern slopes $).$ 


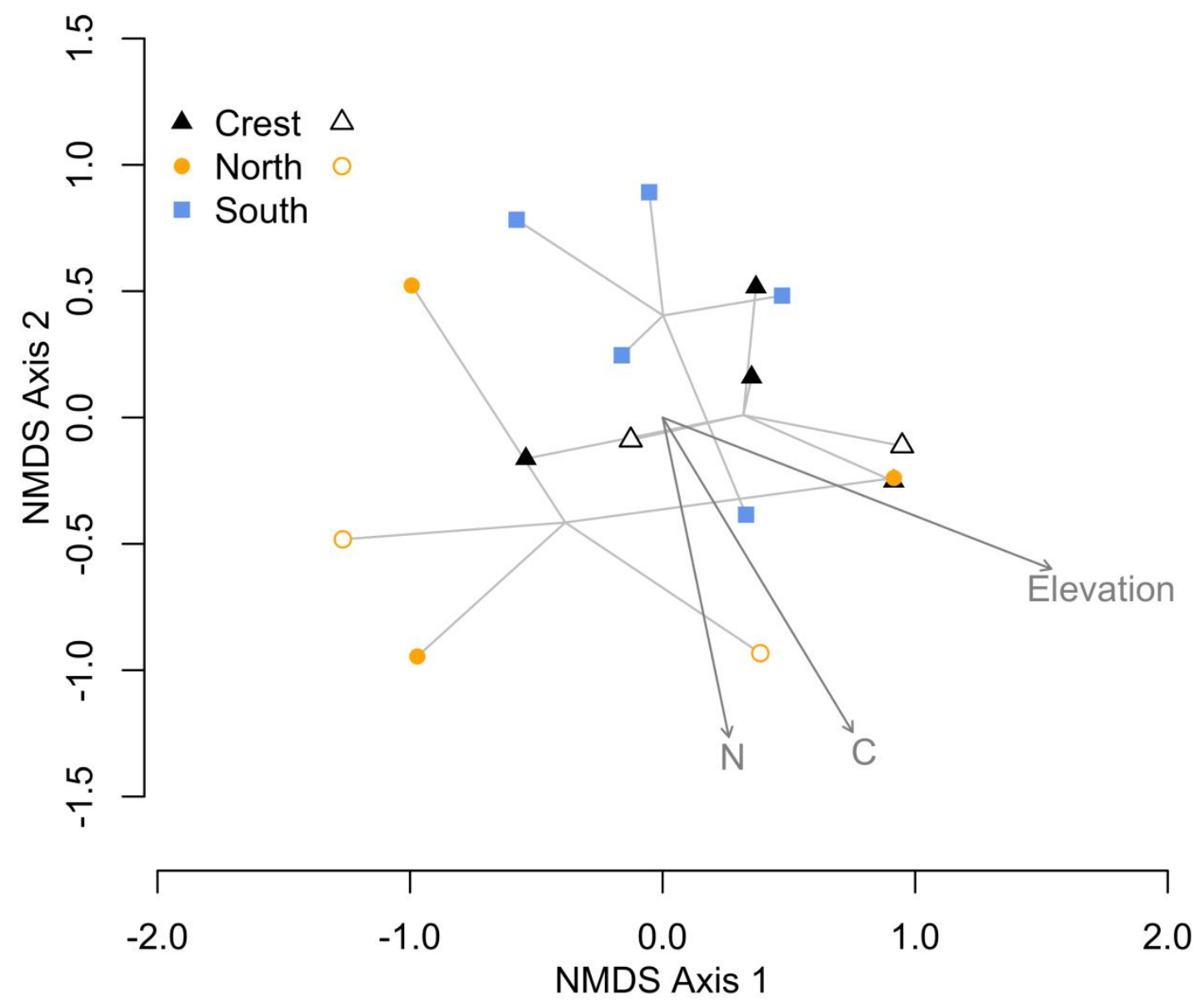

550

551 Fig. 4. Non-metric multidimensional scaling (NMDS) ordination of composition in widespread plots,

552 based on basal area in 2014. Filled symbols indicate plots invaded by Pittosporum undulatum,

553 unfilled symbols non-invaded plots on northern slopes, range crest, and southern slopes. Arrows

554 indicate significant correlations between elevation, soil nitrogen $(\mathrm{N})$ and carbon $(\mathrm{C})$ concentrations

555 with the ordinated vegetation. 


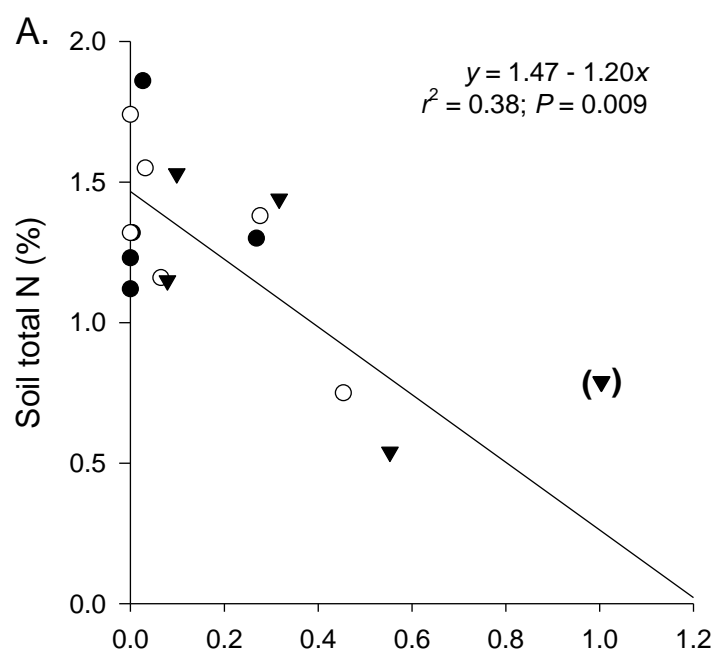

Change in Pittosporum undulatum basal area 557

558 Fig. 5. A: total soil nitrogen (N) concentration (\%) and B: total soil carbon (C) concentration (\%) in 559 relation to annual change in basal area of Pittosporum undulatum across 16 widespread plots in 560 Jamaican montane rain forests (regressions were calculated omitting the bracketed datum with

561 large leverage; black circles = plots on northern slopes, white circles = ridge crest, triangles =

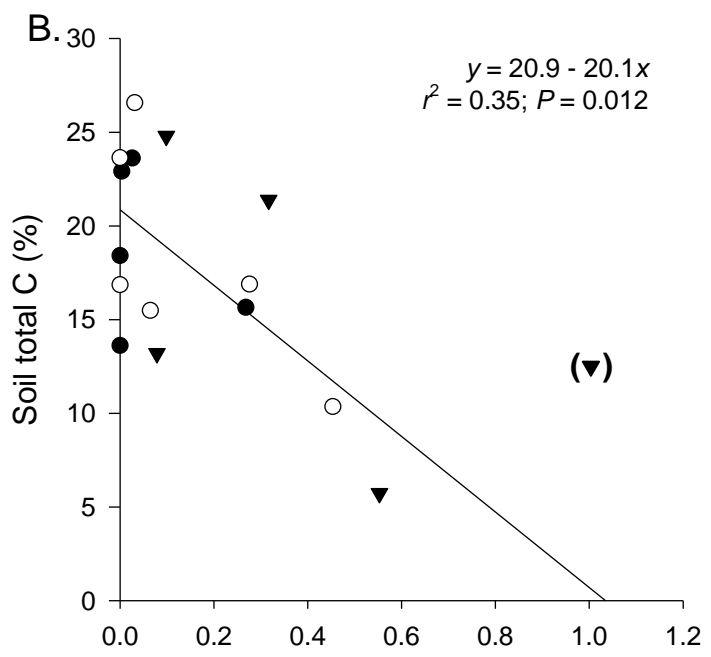

Change in Pittosporum undulatum basal area (m $\left.\mathrm{ma}^{-1} \mathrm{yr}^{-1}, 1990-2014\right)$ southern slopes). 